Original Paper

\title{
Upaya Meningkatkan Hasil Belajar Peserta Didik Pada Materi Agribisnis Pengolahan Hasil Nabati Kelas XII SMKN 1 Sakra
}

\author{
Rohatin Arpianingsih ${ }^{1 *}$ \\ ${ }^{1}$ Sekolah Menengah Kejuruan Negeri 1 Sakra, Indonesia.
}

*Corresponding Author:

Rohatin Arpianingsih, Sekolah Menengah

Kejuruan Negeri 1 Sakra, Indonesia;

Email:

rohatin.a@gmail.com

\begin{abstract}
Abstrak: Untuk mengetahui peningkatan hasil belajar siswa kelas XI SMKN 1 Sakra pada materi pengolahan hasil nabati dengan menggunakan model pembelajaran berbasis masalah. Penelitian ini merupakan penelitian tindakan kelas yang dilaksanakan di SMKN 1 Sakra yang terdiri dari dua siklus dimana tiap siklus meliputi 4 tahap yaitu perencanaan, pelaksanaan tindakan, pengamatan dan refleksi. Data yang digunakan adalah hasil belajar siswa, hasil observasi guru dan hasil observasi siswa. Sabjek penelitian ini adalah ini adalah siswa kelas XII SMKN 1 Sakra yang berjumlah 30 orang. Hasil penelitian ini menunjukan bahwa model pembelajaran berbasis masalah mampu mendorong pemikiran siswa untuk berkembang dnegan cepat dimana aktivitas yang mendukung proses belajar mengajar terus mengalami peningkatan dan aktivitas yang tidak relevan dengan kegiatan proses belajar mengajar berkurang dari pertemuan kepertemuan berikutnya. Berdasarkan hal ini maka dapat disimpulkan bahwa penerapan odel pembelajaran berbasis masalah dapat meningkatkan hasil belajar peserta didik pada materi pengolahan hasil nabati.
\end{abstract}

Kata Kunci: Hasil belajar; Peserta didik; Agribisnis Pengolahan Hasil Nabati.

\section{Pendahuluan}

\begin{abstract}
Upoaya maksimal untuk meningkatkan kualitas pendidikan dan pembelajaran berkelanjutan harus dilaksanakan dengan maksimal dan menyeluruh serta meliputi aspek pengetahuan, keterampilan, sikap. Tentu upaya integerasi aspek ini akan mendorong pengebangan sistem pendidikan yang tangguh agar mampu menghasilkan peserta didik yang siap bersaing diera global (Yubali, 2013, Ety Rochaety, 2006). Dalam pembelajaran agar mudah dimengerti oleh siswa, proses penalaran induktif dapat dilakukan pada awal pembelajaran dan kemudian dilanjutkan dengan proses penalaran deduktif untuk menguatkan pemahaman yang sudah dimiliki oleh siswa (Anas, 2014, Sudarsana, 2016)
\end{abstract}

Beberapa masalah ditemukan dalam pembelajaran di SMKN 1 Sakra salah satunya adalah hasil belajar dan motivasi belajar siswa sangat rendah, sebagian besar siswa belum memenuhi Kriteria Ketuntasan Minimal (KKM).
Hal ini disebabkan karena dalam belajar siswa terlihat bosan dengan metode mengajar yang diterapkan. Dimana peserta didik hanya menyerap informasi yang diberikan guru. Hal ini mengakibatkan siswa bermain dan tidak memperhatikan penjelasan guru. Sementara itu metode pembelajaran konvensional yang digunakan kurang efisien dimana siswa hanya siap menerima penjelasan dari guru kemudian mengerjakan contoh, sehingga siswa sulit dalam memahami materi yang diajarkan. Oleh seban itu diperlukan upaya pengembangan kemampuan berpikir siswa.

Salah satu kelemahan proses pembelajaran yang dilaksanakan pada guru adalah kurang adanya usaha pengembangan kemampuan berpikir peserta didik (Sanjaya, 2007). Dalam proses pembelajaran guru lebih banyak mendorong agar siswa dapat menguasai sejumlah materi pelajaran. Model pembelajaran berbasis masalah merupakan suatu model pembelajaran aktif yang berdasarkan pada penggunaan masalah terstuktur sebagai rangsangan pembelajaran. Peran guru dalam model pembelajaran berbasis masalah adalah 
menyajikan masalah, mengajukan pertanyaan, dan memfasilitasi penyelidikan dan dialog (Rahman, 2018; Santyasa, 2007). Pembelajaran berbasis masalah melibatkan siswa untuk memecahkan masalah melalui tahap-tahap metode ilmiah sehingga siswa dapat mempelajari pengetahuan yang berhubungan dengan masalah tersebut dan sekaligus memiliki keterampilan untuk memecahkan masalah (Bandi, 2015). Berdasarkan uraian latar belakang di atas, maka rumusan masalah yang akan dikaji dalam penelitian ini adalah "Bagaimanakah peranan model berbasis masalah dapat meningkatkan hasil belajar siswa mata pelajaran peternakan kelas XII di SMKN 1 Sakra?" Adapun tujuan penelitian ini adalah untuk mengetahui peranan model berbasis masalah dalam pembelajaran sehingga dapat meningkatkan hasil belajar siswa kelas XII.

\section{Metode}

Jenis penelitian yang digunakan adalah Penelitian Tindakan Kelas. PTK menggunakan model Kemmis dan Mc Taggart Penelitian ini dilakukan pada siswa kelas XII SMKN 1 Sakra semester genap sebanyak 30 siswa. Penelitian ini dilakukan selama 2 siklus pada tahun ajaran $2018 / 2019$. Tiap putaran siklus dilakukan kegiatankegiatan perencanaan, pelaksanaan dan pengamatan, dan refleksi. Sebelum dilakukan PTK, peneliti lebih dahulu melakukan observasi terhadap pembelajaran yang berlangsung untuk menemukan masalah pembelajaran. Dari temuan hasil observasi awal kemudian dirancang atau direncanakan kegiatan-kegiatan perbaikan, mendesain perangkat pembelajaran, dan menyiapkan instrumen penelitian yang akan digunakan selama proses perbaikan pembelajaran. Pada saat penelitian berlangsung guru bertindak sebagai peneliti juga sebagai pengamat atau observer dan berkolaborasi dengan teman sejawat atau guru lain yang bertindak sebagai observer. Selama penelitian, observer mencatat fenomena-fenomena yang terjadi dan kegiatan-kegiatan yang dilakukan oleh guru dan siswa dalam instrumen-instrumen pengamatan yang sudah disediakan oleh peneliti.

\section{Hasil dan Pembahasan}

Berdasarkan hasil penelitian kondisi prasiklus hasil belajar peserta didik sangat rendah, minat dan motivasi peserta didik dalam mengikuti pembelajaran masih kurang, peserta didik belum berani mengajukan pertanyaan, susah menjawab soal, tidak berani mengemukakan pendapat dan kurang aktif. Hal tersebut dijadikan sebagai tolak ukur untuk meningkatkan minat dan motivasi hasil belajar peserta didik sehingga didapatkan proses dan hasil pembelajaran yang lebih baik khsusnya untuk meningkatkan hasil belajar peternakan pada materi pakan ternak rumansia dengan menggunakan model pembelajaran berbasis masalah.

Tabel 1. Nilai ualangan harian dan distribusi frekuensi ulangan harian kondisi awal

\begin{tabular}{lllllll}
\hline No & Uraian & $\begin{array}{l}\text { Ulangan } \\
\text { harian } 1\end{array}$ & $\begin{array}{l}\text { Ulangan } \\
\text { harian } 2\end{array}$ & Interval Nilai & $\begin{array}{c}\text { Ulangan } \\
\text { harian } 1\end{array}$ & $\begin{array}{c}\text { Ulangan } \\
\text { harian } 2\end{array}$ \\
\hline 1 & Nilai rendah & 50 & 55 & $51-60$ & 15 & 10 \\
2 & Nilai tinggi & 80 & 82 & $61-70$ & 10 & 8 \\
3 & Nilai rata-rata & 60,25 & 61,15 & $71-80$ & 6 & 4 \\
4 & Rentang nilai & 30 & 27 & $81-90$ & 4 & 2 \\
\end{tabular}

Berdasarkan Tabel 1 bisa dilihat masih banyak siswa berada di bawah ketuntasan minimal. Pada prasiklus ulangan harian 1 terlihat bahwa nilai tertinggi 82 dan nilai terendah 50 dengan rata-rata 60,25 sedangkan data ulangan harian prasiklus II terlihat nilai tertingi adalah 82 dan nilai terendah 55 dengan rata-rata nilai 61,15 . Penelitian ini dilaksanakan dalam dua siklus. Siklus pertama terdiri dari masing-masing tiga kali pertemuan dan satu siklus terakhir terdiri dari satu kali pertemuan serta disetiap akhir siklus dilaksanakan tes.

\section{Hasil siklus I}

Tahapan pertaman dalah perencanaan. Dalam tahap perencanaan peneliti menyusun perangkat pembelajaran berupa rencana pelaksanaan pembelajaran (RPP) untuk siklus I, soal tes akhir siklus I, dan format pengamatan untuk siswa dan 
guru. Tahap selanjutnya adalah pelaksanaan tindakan. Pada tahap pelaksanaan tindakan dilakukan berdasarkan rencana pembelajaran yang telah disusun pada tahap perencanaan. Siklus I terdiri dari tiga kali pertemuan. Pertemuan pertama dilaksanakan dengan materi yang dibahas yaitu pakan ternak ruminansia. Di akhir pertemuan dilakukan tes akhir siklus I.

Tahap ketiga adalah tahap observasi. Pada pertemuan pertama, guru belum optimal dalam memperhatikan peserta didik, hal ini disebabkan karna kurangnya control peserta didik dalam berdiskusi namun guru hanya memantau peserta didik dari depan kelas. Pada pertemuan kedua, proses pembelajaran belum menunjukkan adanya peninggkatan, melainkan proses diskusi masih didominasi oleh peserta didik yang pandai. Sedangkan pada pertemuan ketiga, terlihat adanya kontrolan guru terhadap peserta didik dalam berdiskusi, pada pertemuan ketiga peserta didik terlihat ada kerjasama namun belum terjadi secara optimal kepada semua peserta didik. Setelah tahapan observasi dilakukan maka dilanjutkan dengan tahapan refleksi. Berdasarkan analisis hasil pengamatan guru, hasil pengamatan siswa, dan hasilbelajar siswa maka dapat diketahui bahwa pada siklus I indikator keberhasilan belum tercapai sehingga perlu diadakan tindakan perbaikan pada siklus II agar hasil belajar siswa dapat ditingkatkan.

\section{Hasil Siklus II}

Tahap perencanaan siklus II. Berdasarkan siklus I maka dengan memperhatikan kelemahan dan kekurangan pada pelaksanaan siklusI dibuat perencanaan sebelum pelaksanaan tindakan siklus II. Selanjutnya Pelaksanaan tindakan. Pada tahap pelaksanaan tindakan dilakukan berdasarkan rencana pembelajaran yang disusun pada tahap perencanaan. Pelaksanaan siklus II sama dengan siklus I hanya saja yang membedakan materinya saja.

Tabel 2. Hasil ulangan harian pada siklus I dan II

\begin{tabular}{lllllll}
\hline No & Uraian & UH 1 & UH 2 & Interval Nilai & $\begin{array}{l}\text { Ulangan } \\
\text { harian 1 }\end{array}$ & $\begin{array}{l}\text { Ulangan } \\
\text { harian 2 }\end{array}$ \\
\hline 1 & Nilai rendah & 60 & 62 & $51-60$ & 13 & 4 \\
2 & Nilai tertinggi & 85 & 98 & $61-70$ & 10 & 10 \\
3 & Nilai rata-rata & 69,05 & 76,50 & $71-80$ & 4 & 6 \\
4 & Rentang nilai & 25 & 36 & $81-90$ & 3 & 6 \\
& & & & $91-100$ & 0 & 4 \\
\hline
\end{tabular}

\begin{abstract}
Hasil observasi terhadap penggunaan model pembelajaran berbasis masalah untuk meningkatkan hasil belajar peserta didik sangat membaik. Adapun aktifitas peneliti pada siklus ini sudah mulai membaik, dimana peneliti mengontrol aktivitas siswa juga sudah mulai terlihat, peneliti selalu berkeliling mengontrol dan memberikan pesertadidik semangat dalam menemukan masalah baru. Akan tetapi peneliti masih kurang tegas dalam mengambil tindakan dan proses pembelajaran. Hasil observasi terhadap guru presentase skor $92 \%$ artinya hasil hasil observasi sangat baik dibandingkan dengan siklus I. Hasil observasi terhadap peserta didik dapat dilihat dari kerjasama dalam mencari hal baru, keaktifan dalam berdiskusi serta keberanian peserta didik dalam memprsentasekan hal baru yang mereka temukan. Sedangkan hasil belajar peserta didik dapat dilihat berdasarkan keaktifan siswa dalam belajar karena dorongan guru yang selalu memberikan motivasi sehingga peserta didik semakin semangat dalam
\end{abstract}

menemukan hal baru, hasil belajar peserta didik semakin meningkat dilihat dari evaluasi mandiri dengan nilai rata-rata 76,50 dan presentase 87,50 $\%$, hal ini menunjukkan bahwa meningkatnya hasil belajar peserta didik sudah tercapai sudah tercapai. Berdasarkan hasil refleksi pada siklus I dengan beberapa hal yang harus diperbaiki pada siklus II yang sudah mengalami peningkatan dalam meningkatkan hasil belajar dengan mengunakan model pembelajaran berbasis masalah pada pengolahan hasil nabati siswa kelas X SMKN 1 Sakra dapat meningkat dari siklus sebelumnya. Berdasarkan tabel diatas dapat direkap nilai tertinggi 85 , nilai terendah 60 dan nilai rata-rata 69,05 pada siklus 1 . Sedangkan nilai tertinggi pada siklus II 98, nilai terendah 62 , dan nilai rata-rata 76,50 . 


\section{Kesimpulan}

Berdasarkan hasil dan pembahasan diatas maka dapat disimpulkan bahwa penggunaan model pembelajaran berbasis masalah dapat meningkatkan hasil belajar peserta didik kelas X SMKN 1 Sakra dalam materi pengolahan hasil nabatil. Hal ini dapat dilihat dengan adanya peningkatan pada hasil tes yang dimulai dari tes akhir siklus I hingga akhir siklus II. Berdasarkan hasil penelitian guru disarankan menggunakan pembelajaran dengan model berbasis masalah karna dengan model tersebut peserta didik dapat mengembangkan cara belajar dengan aktif dan menemukan sendiri sehingga ingatan peserta didik kuat. Dalam pembelajaran guru guru dituntun untuk selalu aktif dalam proses kegiatan belajar mengajar sehingga dapat memberikan dorongan kepada peserta didik agar menjadi lebih semangat dalam mengikuti pembelajaran.

\section{Daftar Pustaka}

Anas, M., \& PdI, M. (2014). Mengenal Metodologi Pembelajaran. Muhammad Anas.

Ani, Yubali. "Penilaian autentik dalam kurikulum 2013." In Seminar Nasional Implementasi Kurikulum, pp. 742-749. 2013.

Asnita \& Gani, Erizal. (2020). Pengaruh Penggunaan Model Berbasis masalah Terhadap Keterampilan Menulis Teks Eksplanasi Siswa Kelas VII SMP Negeri 20 Padang. Jurnal Pendidikan Bahasa Dan Sastra Indonesia, 9(1), 23-31.

Kaliky, Syafruddin. (2017). Meningkatkan Hasil Belajar Trigonometri Melalui Pembelajaran Koperatif Tife Think-Pair-Share (TPS) Siswa Kelas X SMA Muhammadiyah Ambon. Jurnal Peternakan dan Pembelajaran. 5(1), 68-86).

Kristin, Firosalia. (2016). Analisis Model Pembelajaran Berbasis masalah Dalam Meningkatkan Hasil Belajar Siswa SD. Jurnal Pendidikan Dasar Perkhasa, 2(1),90- 98.

Laila, A. N. \& Budhi, W. (2017). Pengaruh Model Pembelajaran Berbasis masalah
Terhadap Prestasi Belajar Fisika. Jurnal Ilmiah Pendidikan Fisika, 4(2), 57-64.

Prasojo, Teguh. (2016). Peningkatan Aktivitas dan Hasil Belajar Peternakan dengan Metode Tutor Sebaya pada Siswa Kelas X IPA 7 Materi Trigonometri SMA Negeri 1 Kudus. Jurnal Peternakan Kreatif-Inivatif. 7(1), 91-98.

Rahman, T. (2018). Aplikasi model-model pembelajaran dalam penelitian tindakan kelas. CV. Pilar Nusantara.

Sani, R. A. (2014). Pembelajaran Saintifik untuk Implementasi Kurikulum 2013.

Santyasa, I. W. (2007). Model-model pembelajaran inovatif. Universitas Pendidikan Ganesha 